\title{
VIVANCO MARTÍNEZ, ÁNGELA \\ Disposición sobre la vida humana y principios constitucionales: Análisis del caso chileno
}

Ediciones Universidad Santo Tomás, Santiago de Chile, 2014.

Este libro, fruto de estudio y análisis de varios años, constituye una publicación derivada del trabajo de la autora para optar al grado de doctor en Derecho por la Universidad de La Coruña y es una valiosa contribución al análisis del texto constitucional tomando como ejemplo el caso chileno. El problema que aborda, de por sí merecedor de debate social, es enriquecido con aportaciones de muy diversas fuentes debidamente ponderadas. Sus conclusiones sirven, más allá del ámbito jurídico, para iluminar el complejo tema de la eutanasia y sus diversas perspectivas desde el punto de vista cultural.

No cabe duda que los textos escritos constituyen la médula de la crítica razonada y razonable que exige el quehacer bioético. Ninguno de los producidos en una nación deja de tener un trasfondo valórico que vale la pena desentrañar, exponer y analizar. En el caso presente, no deja de advertirse que, si bien son esenciales para la discusión, no agotan por completo el asunto. Más bien incitan a profundizar en los criterios de interpretación que exigen tanto las instancias formales como las convicciones, a veces implícitas, de las personas. En este volumen se encontrarán lúcidos y documentados comentarios que exceden su importancia para la comunidad de expertos.

Formalmente, este libro puede ser leído con provecho por quienes se interesan en conocer el proceso de gestación de los textos fundamentales que presiden la convivencia republicana. También por quienes, instruidos ya en las técnicas legislativas, deseen dialogar con la comunidad mayor y contribuir al examen de los fundamentos morales siempre presentes como trasfondo de la concreción documental.

Fernando Lolas Stepke 